\title{
Constitutional Changes and Proposals for Constitutional Changes in the Czech Republic after the Crisis in $\mathbf{2 0 0 8}$
}

\author{
JAN KUDRNA*
}

\begin{abstract}
The article describes the impact of the 2008 global economic crisis on constitutional developments in the Czech Republic. The author does not focus only on monitoring the temporal coincidence of the submitted draft constitutional acts with the events known as the financial crisis, but also their direct substantive links with them. A temporal link is an insufficient criterion. The capital question is, if a causal link based upon a material aspect exists with regard to each specific example. From this viewpoint, the author suggests dividing proposals for constitutional changes in the Czech Republic into four categories described further in the article. The article tries to explain the Czech constitutional context and the very pro-active approach on the part of politicians to the text of the Constitution and proposals for its amendments, which are however seldom signed into law. The author reaches a general conclusion that the financial crisis itself did not lead to constitutional developments in the Czech Republic. On the other hand, the Czech Republic is undergoing a process (independent of the financial crisis) of the erosion of the political system and the system of political parties associated with a certain amount of public distrust in the traditional system of constitutional and political representations, with the emergence of requirements calling for the strengthening of elements of direct democracy and with the rise of new entities, often selfproclaiming them as being definitely not political parties, but non-political civic movements.
\end{abstract}

Keywords: Czech Republic, constitution, constitutional system, political system, political parties, democracy, financial crisis, constitutional changes, debt brake, budget balance, public debt

\section{INTRODUCTION}

The global financial crisis that began in the summer of 2008 with the fall of the US bank Lehman Brothers brought about a profound change in the existing view of the functioning of public administration. In some respects, it highlighted the non-sustainability of the existing models, in others, it encouraged endeavours to look for new approaches. Naturally, it also had an effect on the functioning of states and societies and the rule of law. Hence, the financial crisis brought an impulse that, more or less, affected the constitutional orders of individual states, or at least opened a discussion on new or renewed the discussion on old issues that seemed to have already been overcome. The fact that it has been dealt with by several researchers already ${ }^{1}$ does not mean that the issue is not still topical. Existing publications neglect the Central European region and also, naturally, tend to concentrate on the impact of the financial crisis on constitutions in the narrowest sense of the word. While such a view may be crucial, it may not be ruled out that the financial crisis, with its broad societal impact, could give rise to requirements for changes in the functioning of existing constitutional bodies. Central European countries have a lot in common, including history, especially the most recent history, and similarities in the development of their respective

* Lecturer at the Department of Constitutional Law at Faculty of Law of the Charles University in Prague, kudrnaj@prf.cuni.cz. The paper was developed under the PRVOUK P4 programme and builds on the conference entitled 'Constitutional Changes in Central Europe After the Crisis in 2008', organised on 3 June 2016 by the Budapest-based Nemzeti Közszolgálati Egyetem and co-organised by the Law Institute of the Hungarian Academy of Sciences.

1 See, for example, Contiades (2013). 
societies. It seems worthwhile to try to establish whether any and if so, what changes have occurred at the constitutional level in specific countries within the region and what changes are being considered.

\section{POSSIBLE DIVISION OF PROPOSALS FOR CONSTITUTIONAL CHANGES ACCORDING TO THEIR RELATION TO THE FINANCIAL CRISIS}

The Author believes that proposals for constitutional changes may and should be classified into finer criteria than being merely temporally related to the 2008 financial crisis. The division should take into account the extent to which the individual proposals are closely related to the financial crisis - whether a causal link exists. If the issue is considered from this perspective, then the proposals for constitutional changes may be ${ }^{2}$ divided into four groups.

1. A temporal link exists but there is probably not a causal link

Some examples of such changes in the Czech Republic may include the introduction of a direct presidential election or lifting the lifelong immunity of Members of Parliament in the event that they have not been extradited for criminal prosecution.

2. A causal link may exist but it is not certain.

One example of such a change concerns considerations of extending the scope of competence of the Supreme Audit Office to the economic management of local selfadministrations as well as considerations regarding the audit of the economic management of political parties by the State.

3. A causal link is highly probable.

This case concerns a special set of changes in the area of social rights These changes apply to laws regarding the nature and the constitutional basis of the rights, where the Czech system allows for individual social rights to be defined by law and the constitutional framework is very broad,. The set also includes decisions of the Constitutional Court of the Czech Republic rendered under cases where the Court examined the constitutionality of specific laws which restricted the scope of social rights with reference to the need for austerity at the time of the financial and the ensuing economic crisis.

4. A causal link is apparent

This set of changes includes measures that are collectively referred to in the Czech Republic as the 'financial constitution'. They apply to proposals that were meant to establish at the constitutional level the maximum public debt amount as well as measures that would have to be applied in the event the 'debt ceiling' is reached. Although a causal link is apparent in this case, it will be shown later in the text that these were not measures that only appeared in the context of the 2008 financial crisis either. Still, this particular proposed change of the constitutional framework is considered to be of key importance.

2 The more significant proposals and changes will be dealt with in more detail further in the text. 


\section{THE CZECH CONSTITUTIONAL SYSTEM AND ITS SUSCEPTIBILITY TO CHANGES}

The Constitution of the Czech Republic is usually ranked among rigid constitutions. and such a classification is correct from the formal viewpoint. In order for the Constitution to be amended, a constitutional act must be passed, ${ }^{3}$ i.e., an act approved by both Chambers of the Parliament, where in the Chamber of Deputies at least a 3/5 majority of all Deputies and in the Senate, at least a 3/5 majority of all the Senators present must be secured in order for the bill to pass. ${ }^{4}$ This meets the fundamental requirement stipulated in the area of the theory of the State, according to which a constitution is rigid if the procedure that must be completed for it to be amended is more complex than that required for regular laws. ${ }^{5}$

For the Czech Republic, it needs to be asked, however, to what extent its Constitution is rigid from the substantive point of view. During the almost 24 years of its existence, a total of 9 direct amendments, ${ }^{6}$ of which one has been repealed by the Constitutional Court of the Czech Republic, and a single indirect amendment, have been passed. ${ }^{7}$

These were not insignificant changes. One of them introduced the direct presidential election, which had a rather significant impact on the entire structure of the Constitution. Another addressed the until-then practically unregulated issue of ensuring State security and the functioning of the State during emergencies. However, the same amendment underwent another comprehensive revision during the following year. The mission of the National Bank has been modified; the relationship between the national, international and European law has been adjusted; the mechanism of (self-)dissolution of the Chamber of Deputies has been regulated and other minor changes have occurred, e.g., the way the immunity of Members of the Parliament is regulated.

With a certain degree of simplification, it can be said that a certain not entirely insignificant change occurs in the Constitution of the Czech Republic once in approximately. every 2.5 years. This practice is referred to as 'patching'. ${ }^{8}$ It manifests itself through successive changes of the Constitution of the Czech Republic, with the changes being relatively significant and the problems the changes seek to address being identifiable in the long run. However, a general revision of the Constitution has not yet been considered instead, specific steps are taken, usually when no other alternatives are available.

3 See Art. 9(1) of the Constitution of the Czech Republic.

${ }^{4}$ Both Chambers form a quorum if at least one third of its members are present.

5 Of course, the proposed amendment should fulfill the demands of the art. 9 (2) of the Czech Constitution, which contains the eternity clause. On the other hand the Czech eternity clause is very general in its form and no proposal of constitutional amendment did not refer to it till now. For more details see: Preuss (2016) or also Roznai (2017).

6 This figure does not include certain constitutional acts, such as those amending the constitutional act on the establishment of self-governing regions, which involved changing the name of certain regions. Constitutional acts approving any modifications to the state border are not included in the number either.

7 The constitutional act, which in early 1998, shortened the election term of the Chamber of Deputies.

8 See Kudrna (2013). 
In my opinion, part of the reason underlying this practice is related to the circumstances in which the current Constitution emerged and are, figuratively speaking, inscribed in its genetic code. The following factors played a role in this:

- a short period of time available for the preparation of the text of the Constitution and the turbulence surrounding the preparatory process

- exclusion of the political opposition from the preparatory process

- certain problems had not been sufficiently dealt with and had been put aside to be addressed in the future

- the revolutionary nature of the time during which the Constitution was being prepared.

These four factors combined created an environment back in 1992 that should have led to the approved document being labelled as a mere provisional Constitution. However, that did not happen and the Constitution was meant to be definitive. Yet it had, and was not possible for it not to have, so many gaps and unresolved issues. Although it was not meant to be provisional at first, in reality, it proved to be just that and the gradual removal of the existing gaps ultimately led to a shift in the manner the entire document was viewed. ${ }^{9}$

Either way, especially the third and fourth points led to the conclusion that the Constitution of the Czech Republic required (and indeed still requires) a number of additions and modifications. This fact seems to contradict its alleged rigidity in the substantive sense of the word.

It should be noted that there about 10 to 20 proposals for constitutional changes in the Czech Republic, submitted every election term and in my opinion, this clearly confirms the view that the Constitution of the Czech Republic is not regarded as definitive by a relatively large portion of the political representation.

Such an attitude on the part of politicians, who, moreover, display a relatively broad scope of interests and a good deal of ingenuity, renders any attempt at separating the elements that originated in the 2008 economic crisis somewhat problematic. A certain degree of discrimination is, however, possible. Some proposals for constitutional changes may be identified as evergreens, since they have always been bound to appear since the renewal of democracy in Czechoslovakia in 1989. Some of them include nationwide referenda, direct presidential election; restricting or lifting immunity, especially for Members of the Parliament; a closer definition, or regulation of the relationships between supreme constitutional bodies and, above all, powers of the President of the Republic. All of the four aforementioned topics run through the constitutional history of Czechoslovakia from 1989 and the Czech Republic, like the proverbial red thread. These will be focused on later.

\section{INDIVIDUAL SETS OF CONSTITUTIONAL CHANGES AND OF PROPOSALS FOR SUCH CHANGES WITH REGARD TO THE FINANCIAL CRISIS}

As mentioned above, individual proposals for constitutional changes may be assigned to several groups, depending on their substantive and causal link to the financial crisis. It would be a mistake to only follow the temporal aspect, as in the Czech Republic, there have been a number of constitutional changes that were adopted after 2008, that had been

${ }^{9}$ For details, see the article referred to in the previous footnote. 
discussed for 20 or more years before they were finally passed,. These may also include some elements of a causal link with the financial crisis. It cannot be excluded that the crisis accelerated or intensified certain problems or brought the public's and politicians' attention to them.

\section{Constitutional changes that involve a temporal, yet probably not a causal, link to the financial crisis}

\section{a) Direct presidential election}

The direct presidential election as the initial example of a constitutional change that was adopted, yet only appears to be temporally connected with the financial crisis.

The idea was first presented in Czechoslovakia very early, on 11 December $1989 .{ }^{10}$ by representatives of the Communist Party of Czechoslovakia. It was a fairly ingenious tactical move on their part in negotiations with representatives of civic movements calling for the democratisation of society, which, back then, were only making their initial attempts at assuming power in the country. A direct presidential election, regardless of how unrealistic due to the time required for its preparation, would then complicate the presumed election of Václav Havel, who at that time was not yet well-known enough among the broader Czechoslovak public. On the contrary, this could have benefited the Communist Party's direct candidate or a candidate endorsed by it. ${ }^{11}$ Civic initiatives rejected this election model with Czechoslovakia sticking to the system where the President is elected by the Parliament ${ }^{12}$ as this model may have been the most suitable one for the two-member nationality-based federation.

The idea of a direct presidential election resurfaced at the time of the preparation of the Constitution of the Czech Republic. The Government's proposal foresaw an indirect election, yet various opposition parties presented as many as four alternatives at varying stages of completion. From the four proposals, only those submitted by the Liberal Social Union (LSU) and Czechoslovak Social Democracy (ČSSD) envisaged the very alternative. The latter party is more important in terms of what would follow since it has survived to the present day, unlike the LSU.

It was not until 2001 that the idea of a direct presidential election gained any political relevancy as the topic was embraced by four minor political parties in opposition to the minority ČSSD government supported by the centre-right Civic Democratic Party (ODS). There were two reasons for this interest namely, to dismantle the power union of the two aforementioned parties and also to attract voters.

It was at that time that the direct presidential election became a relevant alternative, which was gradually embraced by the ČSSD and some minor political parties. The final impulse for the adoption of the direct presidential election, which did not occur until 2012, ${ }^{13}$ came from the re-election of Václav Klaus in 2008. The election was practically televised live and was connected with a number of controversies, apparently including the blackmailing of certain Members of Parliament and suspicions of corruption. With the 2013

10 Rudé právo (1989).

11 Suk (2003) especially 212-28.

12 For other details, see for example: Kudrna (2011), Molek (2015) or Wintr, Antoš and Kysela (2016).

13 Enshrined by Constitutional Act No. 71/2012 Coll. 
election approaching, Parliament politicians had lost all credibility, generating little confidence that another presidential election could secure a little more seriousness. ${ }^{14}$

In the final stages of its introduction, the direct presidential election was relatively strongly associated with the idea of transparency in politics. The idea alone may, but does not have to, be connected with the financial crisis. The requirement for transparency will be returned to later.

\section{b) Closer definition of the powers of constitutional bodies and especially those of the President of the Republic}

Regulation of mutual relationships between certain constitutional bodies and a more detailed definition of certain powers (and responsibilities), ${ }^{15}$ namely those of the President, were yet another pressing and lasting topic of discussions regarding the Constitution of the Czech Republic. The discussion is also rooted in the circumstances in which the current Czech Constitution was being drafted. However, to a great extent, it revolves around the position of the President. Certainly, one of the reasons is the fact that the public traditionally regards the very office as standing above politics, which endows its holder - to a certain extent - with qualities that would normally be attributed to a monarch, rather than a politician. The authority the office and its holder enjoy is therefore relatively substantial, which to a great extent coincides with the fact that the foundations of the Czech constitutional arrangement are parliamentary, where the Head of State is primarily expected to play a representative role. An important factor in this is that all of the Czech Presidents until now have had distinct personalities and all of them have also been politically active in the exercise of their office. This naturally led to conflicts with a certain part of the political spectrum, ultimately giving rise to attempts at refining or restricting certain powers.

The issue was first addressed by the Parliament in 1999, when the ČSSD, along with the ODS, prepared a draft amendment to the Constitution, ${ }^{16}$ which defined in closer terms the conditions for exercising certain powers of the President of the Republic and restricted some other powers. At the same time, the draft proposed a modification of mutual relationships between other constitutional bodies. It should be noted that the drafting of the amendment was preceded by numerous decisions of the Constitutional Court of the Czech Republic addressing a range of constitutionally questionable situations. The draft referred to above was adopted by the Chamber of Deputies, but rejected by the Senate.

A number of bills with a similar content were set forth during the years that followed, many of them connected with a proposal to introduce the direct presidential election, yet none of them was passed. A Government bill of this type has recently been submitted to the Chamber of Deputies, ${ }^{17}$ but the deliberations completed so far do not seem to imply that there is a substantial chance that it will pass. Yet, in spite of that, parliamentary parties with a majority that accounts for approx. $75 \%$ of the votes in the Chamber of Deputies express substantial reservations as regards the method in which presidential functions are being performed.

At the same time, it should be noted that the passage of the direct presidential election did not bring about a significant modification of the powers of the President of the Republic.

14 For details, see Kudrna (2011), Molek (2015) or Wintr, Antoš and Kysela (2016).

15 For details see for example Vnenk (2015).

16 Chamber of Deputies' Papers No. 359, Term III.

17 Chamber of Deputies' Papers No. 506, Term VII. 


\section{c) Modification of the immunity of Members of Parliament}

The scope and modifications of immunity of Members of Parliament are popular topics of discussions. This is partly due to one particular aspect of the immunity, namely the permanent exclusion of prosecution of Members of Parliament $r$ unless there is the approval of the respective Chamber of the Parliament.

The 'lifelong immunity' was not enacted under the democratisation process after 1989, nor at the time of the preparation of the Constitution for the Czech Republic. It first appeared in the legal system of Czechoslovakia at the very beginning of the state's existence, namely in Act No. 35/1918 Coll., on the personal inviolability (immunity) of Members of the National Assembly, of 9 November 1918. Since then, it has been adopted, unchanged, with the exception of the 1960 Constitution, which was a political declaration rather than a legal standard and did not contain many of the traditional constitutional instruments that would normally be expected, in all versions of the Constitution that followed.

Such a broad concept has naturally provoked public opposition and had plenty of discussion potential. It is also understandable that Members of Parliament took their time before they finally waived such broadly conceived protection via Constitutional Act No. 98/2013 Coll. Until then, however a score of draft amendments were submitted regarding the modification of this aspect of parliamentary immunity, or immunity as a whole in each election term.

In this case, it should also be noted that discussions regarding the immunity of Members of Parliament were closely connected with requirements for greater transparency in politics and reinforcing the accountability of its actors. The question is to what extent has this process been induced by the 2008 financial crisis.

\section{d) Introduction of nationwide referenda}

The last big issue in the area of constitutional law that has been constantly recurring since 1989 is the role direct democracy should play in the Czechoslovak and Czech constitutional system. The very issue of the scope of direct democracy and its applicability and adequacy is rather complex and provokes certain controversies.

In post-1989 Czechoslovakia, direct democracy emerged as a pressing issue during the initial stages of the democratisation process, when, as mentioned above, representatives of the Communist Party of Czechoslovakia (KSČ) proposed on 11 December 1989 that the new President be elected using a direct election. Reports from that time mention a 'popular vote' election. The idea of introducing direct democracy was quite consistent with the hectic developments at that time,

Yet, it arrived only a year and a half later in the form of Constitutional Act No. 327/1991 Coll., on the referendum. The Act foresaw a popular vote in matters related to the constitutional arrangement of Czechoslovakia, including, if relevant, a split of the country. A determining factor in the further attitude to referendum on the part of many of its former proponents was the fact that when Czechoslovakia was divided in 1992, the instrument was not used. This had an effect on the attitudes of many politicians and some political parties, especially those on the left. Referendum featured in three of the four alternative drafts of the Constitution for the future Czech Republic, namely those submitted by the ČSSD, LSU and the Left Bloc. 
In its adopted version, the Constitution of the Czech Republic addresses the issue under Art. 2(2), which stipulates that a constitutional act may determine the instances in which the people exercise power directly.

In a nutshell, it may be said that not one election term has passed without the submission of several draft constitutional acts regarding the general referendum, with frequent proposals for one-off referenda regarding certain specific issues on top of that. None of the drafts has ever been adopted, except for Constitutional Act No. 515/2002 Coll., on the Referendum on the Czech Republic's Accession to the European Union. A Government bill of this type has recently been submitted to the Chamber of Deputies, ${ }^{18}$ but, once again, the chance of the bill being passed seems flimsy for now.

As regards direct democracy, the issue has recently been brought up in connection with a certain disillusionment on the part of society with traditional political parties and the growing tendency to weaken them. In the Czech Republic, the concept of direct democracy tends to be ever more strongly advocated by newly emerging, often single-serving political groups, established by both individual politicians and groupings who believe that the disillusionment may be cured by strengthening the element of direct democracy. The first tendency is, however, much stronger in the Czech Republic. Again, the calling for nationwide referenda does not seem to have been induced by the 2008 financial crisis.

\section{e) Other proposals for constitutional changes during 2008-2016}

As it has been mentioned several times, frequent deputies' initiatives to amend the Constitution in various ways form a certain parliamentary tradition in the Czech Republic. Considering their numerousness and broad scope, an overview of such initiatives, without any analyses will be provided. These initiatives all have one thing in common: they have not been passed. However, this did not prevent them from being resubmitted after the election, during the new election term.

V. election term of the Chamber of Deputies (2006-2010):

- nationwide referendum, ${ }^{19}$

- direct presidential election,

- referendum on whether a direct presidential election should be enacted

- loss of mandate for Members of Parliament in the event of their leaving the political party on whose ticket they have been elected,

- lifting the criminal and offence immunity of Members of Parliament,

- refining the powers of the President of the Republic,

- extending the scope of competence of the Supreme Audit Office to the economic management of local self-administrations, ${ }^{20}$

- shortening the election term of the Chamber of Deputies ${ }^{21}$ with the subsequent adoption of a permanent mechanism of self-dissolution of the Chamber of Deputies.

18 Chamber of Deputies' Papers No. 559, Term VII.

19 A draft constitution act concerning a referendum on the location of a missile defence system in the Czech Republic was also submitted in 2006.

20 This proposal will be described in detail in the upcoming section.

21 This constitutional act was repealed by the Constitutional Court on 10 September 2009. For details, see Kudrna (2010) or Preuss (2016). 
VI. election term of the Chamber of Deputies (2010-2013):

- draft of the so-called financial constitution, i.e. the norm on the limit of and measures for restricting the public debt, ${ }^{22}$

- direct presidential election, ${ }^{23}$

- nationwide referendum,

- reducing the criminal and offence immunity of Members of Parliament,

- referendum on church restitutions,

- extending the scope of competence of the Supreme Audit Office to the economic management of local self-administrations, ${ }^{24}$

- subsuming the abolition part of the right of the Presidential pardon to a countersignature by the Prime Minister

- introduction of an effective presidential system,

- constructive vote of no confidence in the government,

- loss of mandate for lawfully convicted Members of Parliament,

- direct election of mayors and governors.

VII. election term of the Chamber of Deputies (2013-2017):25

- draft of the so-called financial constitution, i.e. the norm on the limit of and measures for restricting the public debt, ${ }^{26}$

- extending the scope of competence of the Supreme Audit Office to the economic management of local self-administrations, ${ }^{27}$

- nationwide referendum,

- refining the powers of the President of the Republic and other constitutional bodies and regulation of their mutual relationships,

- introduction of the so-called sliding mandate,

- lifting the immunity of Members of Parliament,

- direct election of deputies and governors,

- referendum on leaving the European Union,

- restricting the term of office of constitutional judges to a single term and its extension to 12 years.

The above list above confirms the claim that most Members of the Chamber of Deputies are vigorous proponents of constitutional changes and the proposed spectrum of changes is very diverse. This, at the same time, supports the contention that a significant number of Deputies tend to approach the Constitution as a work-in-progress.

Yet, none of the changes listed in this overview, bah the exceptions identified, are related to the 2008 financial crisis. The direct election of mayors and governors has emerged

22 This draft and its future fate will be described in detail further in the text.

23 The draft was finally approved after numerous amendments, see above.

24 This proposal will be described in detail in the upcoming section. During the election term under consideration, the draft was simultaneously submitted three times by three different proponents.

25 The situation described was effective at the time the present paper was written, i.e., in the second half of 2016.

26 This draft and its future fate will be described in detail further in the text.

27 Extending the scope of competence of the Supreme Audit Office to the economic management of local self-administrations, 
as a new topic in the Czech Republic and I am convinced the proposal will re-emerge during the election terms to follow. Regards this topic, I am ready to concede there is a connection with a certain loss of confidence in traditional political parties and the political system. 'traditional' means the system and its actors who have operated in the Czech Republic for the last 25 years, even if with certain evolutionary transformations.

\section{CONSTITUTIONAL CHANGES FOR WHICH A CAUSAL LINK WITH THE FINANCIAL CRISIS MAY EXIST, BUT IS NOT CERTAIN}

The category of bills where a possible causal link to the financial crisis in the Czech Republic exists includes a single draft amendment to the Constitution, namely a proposal to extend the scope of competence of the Supreme Audit Office (NKU) to the economic management of territorial self-governments and legal entities with a state property stake or of territorial self-governing units. ${ }^{28}$

These intentions, as mentioned above, have a relatively long history. In the Czech Republic, they originate in a general political and legal campaign against corruption, rather than in the need to streamline the economic management of territorial self-governing units, e.g., fiscal reasons. The very concept is a component part of endeavours to tackle corruption in the Czech Republic, which have mostly been initiated by the numerous non-government organisations operating in the country. Their other component parts include, without limitation, tightening some provisions of the Public Procurement Act; strengthening the transparency of public procurement contracts concluded by public-law corporations by means of disclosing such contracts under the sanction of their nullity; proving the origin of property or tightening the rules on the conflict of interests.

It started to appear in the Czech Republic that the economic management of local selfgoverning units may not be entirely flawless although central public administration bodies and the entities subordinated to them manage a crucial part of public finances. For example, at the regional level, a number of cases of misuse of substantial EU subsidies were revealed, ultimately leading to final judgments and criminal sentences.

The described process of disclosure, investigation and sentencing of misuse of EU subsidies may represent an internal source of the requirement for changes and for extension of the authority of the Supreme Audit Office, which enjoys a favourable reputation in the Czech Republic.

External factors, may also play a role in this respect. One of them may be the influence of the European Union, which seeks to achieve sufficiently effective oversight in respect of the manner in which especially European subsidies are administered but their origin may also be purely international. In part, the situation might have also been caused by assessments of non-government organisations, such as Transparency International, as well as by initiatives developed by the International Organisation of Supreme Audit Institutions (INTOSAI). This mainly concerns the Lima Declaration the organisation adopted in 1977

28 During certain periods, the possibility of trusting the audit of these entities to the Supreme Audit Office was considered as part of the measures designed to ensure greater transparency of the economic management of political parties. As regards this issue, the existing constitutional framework includes a decision of the Constitutional Court of the Czech Republic published under No. 296/1995 Coll., which excludes such a possibility, including where the audit would be restricted to the management of public contributions to the operation of political parties. 
and the Author is convinced the external factors described above are not directly related to the 2008 financial crisis.

In any event, strengthening the powers and extending the competence of the NKU emerged as a relevant political issue in 2010. At that time, these issues were incorporated into the Government's policy statement of 4 August 2010. The document expressly specified that the strengthening of audit powers would especially be applied with regard to territorial self-governing units. The intention was contained in a part dedicated to fighting corruption.

It is because of this consideration, no matter how formal, that it can be assumed that the extension of the NKU's powers was related to the 'anti-corruption wave' rather than to the direct need to respond to the financial crisis.

The VI. election term of the Chamber of Deputies (2010-2013) was record-breaking from the viewpoint of the proposals to extend the NKU's powers, since the draft amendment to the Constitution was submitted three times. ${ }^{29}$ All of the drafts also foresaw extending the NKU's audit powers to corporations in which the State holds a property stake or to territorial self-governments. The government draft successfully passed through the Chamber of Deputies and was only rejected by the Senate, the other two drafts did not even get past the first reading and were not even discussed by the Chamber of Deputies before the end of the term.

The so-called caretaker government presided over by Jiří Rusnok, which rose to power after the fall of Petr Nečas's administration and which was expected to guide the country towards an early election, did not come forward on this issue in its policy statement.

The policy statement of the Government appointed in 2014 mentions the extension of the NKU's powers and competence in two places, in both cases with an emphasis on increasing the efficiency and transparency of the controls and on removing duplicities in the existing controls.

The current Government also submitted the respective draft constitutional amendment, ${ }^{30}$ yet it was rejected by the Senate on the 26 May 2016. The Senate, in its decision, called upon the Government to submit the proposal again, but this time in a version that respects the Government's own policy statement, i.e., in such a form that would allow for the controlling duplicities to be removed as promised.

In summing up the issue of extending the NKU's competence, there have been two mutually opposing tendencies in this area in the Czech Republic in recent years. On the one hand, transparency of economic management is stressed. For the proponents, the Supreme Audit Office constitutes a certain guarantee of independence since it is viewed as a professional, rather than a political body. ${ }^{31}$ On the other hand, there is a tendency to reject further oversight mechanisms, possibly combined with the question as to how much selfgovernance may be exercised by territorial self-governing units if they are subjected to the NKU's oversight, which is by the opponents of the proposal understood as another state intervention into the territorial self-government, moreover superfluous in their opinion as there exists quite a lot of state control mechanisms.

29 The first proposal came from the Government, namely Paper No. 351, the other two were submitted by Deputies, Papers No. 918 and No. 969. All of them were submitted during Term VI.

30 Chamber of Deputies' Papers No. 610, Term VII.

31 Considering the way in which the NKU is constituted, this hypothesis is somewhat open to discussion; on the other hand, nobody has ever claimed or proved that the NKU conducts its audit tasks in a biased or partisan way. 
The latter view is mainly proposed by representatives of the Union of Towns and Municipalities of the Czech Republic, an association defending the interests of municipalities. To anyone familiar with the situation in the Parliament, it should come as no surprise that the view is mainly supported by members of the Senate, who are well-known for the enthusiasm with which they pile up functions also on territorial self-governments. In a way, Senators, in themselves, embody a very specific conflict of interests. ${ }^{32}$

In conclusion, it may be said that the described draft amendment to the Constitution is related to the strong theme of combating corruption and promoting transparency in public life, which emerged in the Czech Republic around 2010. However, the question is to what extent this process had been induced by the 2008 financial crisis.

\section{CONSTITUTIONAL CHANGES FOR WHICH A CAUSAL LINK TO THE FINANCIAL CRISIS IS HIGHLY PROBABLE}

The third category of proposals and changes is rather specific, as, while strongly coinciding with the 2008 financial crisis in the Czech Republic, it only includes substantive changes and proposals for changes in matters regulated by constitutional regulations. No changes to constitutional regulations occurred from the formal viewpoint. This category includes, without limitation, interferences with social rights effectuated through acts and other legal regulations.

In the Czech Republic, social rights are defined, at the constitutional level, by the Charter of Fundamental Rights and Freedoms (hereinafter referred to as the "Charter") 33 and they may be consulted in Heading Four of the regulation. Their legal base is different from that of basic, political or civil rights. In this respect, the Czech Republic does not differ from other states guaranteeing social rights at the constitutional level.

First and foremost, the constitutional regulation of social rights is distinct by being generic rather than detailed. The Charter, in its formulations, usually only defines the aim or protected interested and when it comes to details, references the law. The legislator therefore plays a major role in defining social rights. This concept is further supported by Art. 41(1) of the Charter, which stipulates that the listed rights may only be enforced within the bounds of the laws that implement them.

As a result, the legislator enjoys relative freedom in determining the scope of social rights. Naturally, this is related to the character of the rights, which - in order for the rights to be fulfilled - requires compliance on the part of society, or the State and its scope depends, to a great extent, on the performance of the economy,

However, the legislator is not entirely unlimited in its decision making. A general limit is defined under Art. 4(4) of the Charter, which stipulates that the essence and significance of fundamental rights and freedoms must be preserved when their limits are determined. A consequence is that the legislator, with its decision, defines the scope of social rights, but may not deny their essence and significance; it may not cancel any right by enacting a law that vacates its content.

32 As a side note, refusing the NKU's oversight for self-governments on the grounds of the alleged interference with their self-governing function for fears that the NKU could audit not only the legality, but also the efficiency of the manner in which public funds are managed, is somewhat unfounded since the existing legislation imposes upon both municipalities and regions the obligation to manage their assets both economically and effectively.

33 Published under No. 2/1993 Coll. 
This is confirmed by the constant case law of the Constitutional Court in this matter in the Czech Republic, the decision making regarding the scope of social rights is largely a political question, where the legislator must only respect a certain minimum standard. This in turn, implies the need for a certain restraint on the part of the Constitutional Court when assessing the constitutionality of the related implementing regulations, especially in comparison to fundamental, civil or political rights. The Constitutional Court maintains that the essence and significance, i.e., the essential content of any social right, will always be subject to a review of its constitutionality. ${ }^{34}$

Consequently, although social rights are enshrined constitutionally in the Czech Republic, their scope may be altered by mere laws. Unlike the matters discussed above, this is a special case where a constitutional matter is formally regulated by common laws. With its essence, however, I am convinced it is relevant to the issue under consideration.

The 2008 financial crisis also had an impact on the budgets of states, including the Czech Republic. The Czech Governments administering the country especially during the 2008-2013 period adopted a range of austerity measures, including those applying to social rights. In practice, changes occurred in a number of areas, ranging from health service, via social services up to social security and unemployment benefits. It needs to be noted though that some of the measures had already been considered before that.

\section{a) Regulatory fees in the health sector between 2008 and 2014}

The first example concerns the introduction of so-called regulatory fees in the health sector. Access to healthcare in the Czech Republic is regulated under Article 31 of the Charter. The provision stipulates that citizens of the Czech Republic shall have the right, on the basis of public insurance, to free medical care and to medical aids under conditions provided for by the law.

In practice, the public health insurance system worked and now works again, in such a way that a patient at a healthcare establishment financed from the public insurance system does not have to make any additional payments in respect of their treatment. With respect to prescription drugs, there must be a single drug in each category that is fully covered by the health insurance company.

The centre-right government coalition that assumed power in 2006 modified the system when on 21 August 2007, it adopted an amendment to the Public Health Insurance Act, based on which so-called regulatory fees were collected starting from 1 January 2008. In reality, an amount of CZK 30 was collected for each doctor's appointment, CZK 30 for each prescription issued, CZK 60 for each day of hospitalisation and CZK 90 for a visit to an emergency department.

The truth is the fees were introduced about a year before the onset of the global financial crisis, yet the arguments offered at the time of their passage and during their subsequent repeated discussions, were identical to those expressed later on at the time other austerity measures were introduced. After all, this was also reflected in the title of the respective act, which read 'Stabilisation of Public Budgets'.

34 The Constitutional Court commented on this issue for the first time on 13 June 1995, under its decision Pl. ÚS 25/94; for its last decision so far see decision Pl. ÚS 55/13 of 1 June 2016. 
The regulatory fees underwent further evolution since they provoked much public resentment ${ }^{35}$ and their impacts in many respects went against their original purpose, namely to "regulate" healthcare overuse.

The opposition ČSSD along with KSČM even challenged the amendment to the Public Health Insurance Act before the Constitutional Court on 22 October 2007. The Court resolved the proposal with its judgment No. Pl. ÚS 1/08 of 20 May 2008, by rejecting it.

There is no point in analysing the judgment as such but it is important that the Constitutional Court referenced the special nature of social rights, as defined above and regarded as the determining factor whether, or not, the act denied the underlying significance of the constitutionally guaranteed right to free healthcare. The Court did not find that to be the case and recalled that in the area of social rights, the legislator must not deny the existence and implementation of such rights but other than that has plenty of room for their own discretion,

With this decision, the regulatory fees could continue to exist and the decision whether they should be removed would be left to the discretion of the Chamber of Deputies. Still on 1st August 2008, new-borns at neonatal establishments were exempted from the fees and on 1st April 2009, the fees ceased to be collected from all children below the age of 18. On the other hand, on 1 December 2011, the hospitalisation fee was increased from CZK 60 to CZK 100 per day. On 12 April 2012, the Ministry of Health announced its plan to increase the fee for a doctor's appointment to CZK 50 and introduce a specialist doctor's appointment fee without GP recommendation to several hundreds of Crowns, depending on the type of specialisation,

The Constitutional Court had to deal with the regulatory fees once again, after a group of ČSSD Deputies submitted their proposal on 14 December 2011. Amongst other things, the proposal challenged the increase in the daily hospitalisation fee from CZK 60 to CZK 100. The decision was rendered with judgment Pl. ÚS 36/11 of $2^{\text {nd }}$ July 2011.

In this judgment, the Constitutional Court concluded that the increase in the fee amount was unconstitutional due to the absence of any discrimination based on the social situation of the payer and the absence of any limit of the fee amount linked to the length of the hospitalisation. As a consequence, in this case, the Constitutional Court already identified inadmissible interference with the essence of a constitutionally based social right.

The Constitutional Court suspended the operation of its decision in this matter to 31 December 2013. The caretaker government presided over by Jiři Rusnok then submitted a draft act on 6 November 2013 reintroducing the daily hospitalisation fee at CZK 60, which would not apply to hospitalised children under the age of 18 . The newly appointed ČSSDled Government however, retracted the draft later on and starting on 1 January 2014, the daily hospitalisation fee ceased to be collected. All so-called regulatory fees in the health sector were repealed as of 1 January 2015, except for the CZK 90 fee for using emergency medical services.

The example described above shows that efforts to stabilise public budgets in the Czech Republic had an effect on the form of constitutionally guaranteed rights. The efforts were also reflected in the methodology applied by the Constitutional Court, which specified

35 Opposition to the regulatory fees, among other things, led to the overwhelming victory of the Social Democrats in the regional elections in autumn 2008, when the opposition party emerged victorious in all 13 regions. 
a procedure to be used when assessing the constitutional conformity of similar interferences with social rights.

At the same time, the partial charging of public healthcare services (and its subsequent repeal) shows that there is some room left for the Czech government to exercise its discretion in making decisions regarding the scope of social rights.

\section{b) Introduction of the so-called public service}

Another potential example of a change in the area of social rights which might have coincided with the introduction of austerity measures is the enactment of the so-called public service instrument in the Czech Republic. A new condition for the payout of unemployment benefits was introduced on 1 January 2012 for people who had been unemployed for over 2 months. The condition concerned their willingness to engage in socalled community work, i.e., work performed in favour of municipalities, - in certain cases, the service could also be performed in favour of private entities. Although the legal system of the Czech Republic had previously incorporated public service as an enabling instrument for people in material need, whose amount of social benefits could be increased if they joined community service, the instrument underwent a certain qualitative transformation during the period indicated above. As a novelty, after the lapse of two months of unemployment, the payout of unemployment benefits was conditioned by completing public service, at a quadrupled intensity compared to what the case was until then, at the discretion of the Employment Office.

Apparently, the change in the essence of the existing legal instrument was substantial, as was the scope of interference with the constitutionally guaranteed right to unemployment benefits and benefits in material need.

The Act described above was challenged at the Constitutional Court by a group of ČSSD Deputies on 6 January 2012 and the Constitutional Court granted their proposal through judgment Pl. ÚS 1/12 of 27 November 2012. In its decision, the Court agreed with the claimants that the Act contravened the prohibition of forced labour pursuant to Art. 9 of the Charter. The legislator therefore principally breached Art. 4(4) of the Charter and entirely deviated from the area of social rights to interfere with fundamental rights and freedoms of individuals.

The two examples referred to above may suffice to illustrate interferences with constitutionally guaranteed rights, which may occur through common laws and which may alter the very content of such rights. The Constitutional Court of the Czech Republic noted that such approach is possible, yet it must not affect the very essence and significance of the regulated right. The two examples show both a measure found to conform to the Constitution and a measure rejected on the grounds of being constitutionally excessive. At the same time, they both exhibit tight links to the 2008 financial crisis and the need for austerity in public budgets.

\section{CONSTITUTIONAL CHANGES FOR WHICH A CAUSAL LINK TO THE FINANCIAL CRISIS IS APPARENT}

The last group, which contains proposals for constitutional changes that are tightly linked to the 2008 financial crisis, includes all that is referred to in the Czech Republic as the 'financial constitution'. In other words, the constitutional enactment of the limits for overall public debt and for annual public budget deficits including austerity measures in case the overall public debt threshold is achieved. 
Such regulation is absent in the Czech constitutional system. This distinguishes the Czech Republic from countries that have had this regulatory safeguard, sometimes referred to as a 'debt brake', for a relatively long time, such as Poland since 1997 and those for whom it represents a relative regulatory novelty, such as the Slovak Republic, which only introduced the instrument in 2011. However, within the European Union, the Czech Republic is no exception due to the absence of constitutional regulation of the public debt limit, not even among Member States of the euro area.

This naturally does not mean that the issue has never been discussed since the establishment of the Czech Republic in 1993. It became the centre of attention several times during the latter half of the 1990 s, when the concept was introduced by the then Prime Minister, Václav Klaus and again in 2002 when, already as a regular Member of Parliament, Klaus, along with his colleagues, submitted a bill of a constitutional act on budgetary discipline. ${ }^{36}$ However, both of these initiatives were more than anything else examples of political marketing of the centre-right ODS, since the party did not even endeavour to push the bill through at the time when its chairman led a majority government.

Generally speaking, the very idea of capping public debt is not a novelty, originating within the European Union long before the outbreak of the financial crisis in 2008. The first limit was introduced in the context of the Treaty of the European Union, which requires, as one of the so-called convergence criteria, or the conditions for the introduction of the euro, that the public debt of an acceding Member State must not exceed a threshold of $60 \%$ of GDP and that its public budget not exhibit a deficit in excess of 3\% of GDP. Many states established these limits at the constitutional level as part of their preparations for the future adoption of the euro.

It should also be noted that further development in this matter at the EU level and at the level of the Member States was twofold. On the one hand, after 1992, the conditions for the functioning of public budgets further evolved with additional conditions established institutionally, especially with regard to the sustainability and predictability of public budgets. On the other, however, a certain number of states did not succeed in meeting either of the convergence criteria defined above, or merely approached their fulfilment. Individual states responded differently to this fact. Some assumed a creative stance, for example, with regard to pension funds (such as Poland, Hungary or Slovakia); others were granted exceptions or were penalised for not complying with the rules (such as Germany, France or Italy) and other states, which displayed a high degree of budgetary discipline, such as Lithuania, Latvia or Estonia, experienced the very severe economic and social impacts of the austerity measures they had introduced.

The above shows that enacting debt ceilings and debt brakes at the constitutional level is not a universal solution and is relevant politically, rather than legally, while it may be very difficult to comply with them from the political or social point of view.

At this point, it may be said that the very idea of imposing limits on public debt substantially predates the 2008 financial crisis, yet considerations of rendering such caps

36 Chamber of Deputies' Papers No. 115, Term IV. The basic parameters of the bill were designed in such a way that a public budget with a deficit up to $2 \%$ of the GDP would require a mere absolute majority of all MPs present to be passed; the passage of a deficit higher than $2 \%$, but not exceeding $3 \%$ of the GDP would require an absolute majority of all MPs; and a deficit over $3 \%$ of the GDP would only be passed if a constitutional majority, i.e., at least $3 / 5$ of all MPs, were for it. The draft only received 49 support votes. 
binding at the constitutional level are tightly linked to the crisis, at least in the Czech Republic.

The centre-right administration led by Petr Nečas subscribed to the idea of adopting a so-called financial constitution in its policy statement of 4 August 2010. The coalition agreement regulating the underlying objectives of its activity contained a stipulation according to which the coalition was to press for the adoption of a constitutional act, including the related mechanism enshrining direct accountability of politicians in the area of public finance management. The government's policy statement confirms the constitutional level of the envisaged regulation.

The political intention of the government at that time was to prepare a very detailed and strict regulation. ${ }^{37}$ The so-called debt brake was designed as a multi-stage instrument with fiscal and procedural restrictions starting to apply well below the $60 \%$ public debt level with regard to GDP. Initial measures were meant to be applied already upon reaching a public debt amount equal to 44\% of GDP. Austerity measures should have been applied automatically and, in addition to salary reductions in the public sector, included pension cuts and reductions in the scope of healthcare services financed under the public health insurance system. The relevant implementing act was meant to be subsumed to the regime described under Art. 40 of the Constitution of the Czech Republic, i.e., any changes therein would have had to be approved by both Chambers of the Parliament. The Government incorporated the details in its Resolution No. 253 of 11 April 2012.

The 'financial constitution', as conceived was also meant to be used as an instrument implementing European Directive 2011/85/EU on requirements for budgetary frameworks of Member States. From the viewpoint of the then Government, making that connection did not turn out to be entirely satisfactory, since in relation to the aforementioned Directive, its intention to create a strict and extensive financial constitution represents a typical example of 'gold-plating', This combined with the fact that the Government did not have a constitutional majority and that for the opposition, the draft financial constitution was unacceptable in its form at that time, resulted in a situation where the financial constitution was not implemented in the Czech Republic.

Petr Nečas's administration therefore did not succeed in pushing the financial constitution through and the Jiří Rusnok-led transitional government that followed it could not do so either due to the early election and the overall disintegration of the Chamber of Deputies.

The newly established centre government with Bohuslav Sobotka as Prime Minister did not commit to adopting the financial constitution in the coalition agreement, or its policy statement. On the other hand, it inherited the aforementioned resolution adopted by Petr Nečas's government, which remained valid and binding.

This was reflected in a draft constitutional act and implementing acts implementing the resolution of the previous administration, submitted by the Ministry of Finance in May 2014. It soon became evident that the very concept of a constitutional act that leads to automatic cuts in social and healthcare expenses in the event a certain level of public debt is reached is unacceptable for Social and Christian Democrats. Both parties were only willing to go as far as requiring general constitutional regulation that would numerically correspond to the convergence criteria and make compliance with the criteria mandatory, yet at the

37 One of the parties comprising the coalition at that time headed into the 2010 election with a slogan that said that they would protect the country from 'taking a trip to Greece'. 
same time would leave enough room for each government to determine its own priorities and areas where it would make cost cuts and those where any austerity measures would be avoided. Both parties based their view upon the aforementioned case law of the Constitutional Court. The fact that the level of public debt in the Czech Republic is declining and that in 2016, it amounts to less than $41 \%$ of GDP, also played a role in their views.

The first step adopted on the way towards formalising the altered view involved cancelling the task imposed through Government Resolution No. 253 of 11 April 2012. That happened, following lengthy deliberations, through Government Resolution No. 777 of 22 September 2014. Intensive negotiations were in progress in the months that followed between members of the ruling coalition regarding the future form of the financial constitution, culminating in the Government passing Resolution No. 114 of 23 February 2015, whereby it adopted a draft constitutional act on fiscal responsibility and submitting it to the Parliament for approval. ${ }^{38}$

Compared to the previous government plan, the financial constitution underwent some major changes, which moved it closer to being a general framework. Generally speaking, the draft contains an obligation on the part of public institutions ${ }^{39}$ to ensure sound and sustainable public finance management and unlike the previous plans, contains a stipulation that while performing this task, the institutions should appropriately encourage economic and social development, employment and intergenerational coherence. In their economic management, public institutions must proceed economically, transparently, effectively and efficiently. Also, they must ensure the public debt evolves in a way that does not compromise the long-term sustainability of public finances.

In addition to the aforementioned overwhelmingly declarative provisions, which contain principles already incorporated into the legal system of the Czech Republic, the draft constitutional act on fiscal responsibility also contains three normative elements.

First, it establishes the National Budgetary Council as an independent body overseeing compliance with the rules of fiscal responsibility. The task of the Council is merely to evaluate the situation. Also, it stipulates that the National Budgetary Council must have three members elected by the Chamber of Deputies.

The draft constitutional act imposes upon territorial self-governing units the obligation to comply with the rules of fiscal responsibility. In this respect, it is questionable whether the draft brings anything new, since territorial self-governing units are already inherently subordinated to the law. Moreover, Art. 101(4) of the Constitution already makes it possible for the State to interfere in the activity of territorial self-government units in the interest of protecting the law.

The most important in terms of content, however, is the third provision, which stipulates the level of public debt that triggers austerity measures. The draft sets the level at $55 \%$ of GDP. The limit is set at less than $60 \%$ of GDP due to certain inertia in fiscal development, where austerity measures do not take an immediate effect, so as to ensure

38 Chamber of Deputies' Papers No. 411, Term VII.

39 Public institutions here denote the State, territorial self-governing units and other institutions specified by the implementing act (such as public health insurance companies, public universities, allowance organisations established by the State and self-governments, etc.). In the Czech Republic there are in total about 18,000 such entities. 
(if possible) that the public debt never exceeds the limit of $60 \%$ of GDP. In other words, the extra $5 \%$ of GDP is set as a kind of 'braking zone'. ${ }^{40}$

All details, including those on the austerity measures to be adopted, are meant to be specified by an implementing act. ${ }^{41}$ The intention for the implementing act to require the approval of both Chambers to be passed has been abandoned. Hence, the act will be approved under a regular legislative process, which means that if required the Chamber of Deputies will have the chance to outvote the Senate. This modification has been justified with a reference to the need to harmonise it with the provision under Art. 42(2) of the Constitution, according to which a bill of an act on the state budget shall only be discussed by the Chamber of Deputies.

As shown above, the complex of draft regulations on fiscal responsibility has undergone some major changes under the new administration, compared to the strict concept introduced by the previous government. The former concept was particularly unacceptable for the Social and Christian Democrats. Yet, it should also be added that the coalition currently in control does not hold a constitutional majority and needs the endorsement of at least a part of the opposition for its bills to be passed. This is also one of the reasons why adoption remains the only way to implement Directive 2011/85/EU.

Amid the current situation, the bill as such is ideologically unacceptable for the section of the opposition represented by the Communist Party. For the right-wing part of the opposition comprised of former government parties, the draft is unacceptable for its leniency, with the parties specifying as a condition for their endorsement of the draft the stipulation of binding rules for achieving a balanced budget over the upcoming years at the constitutional level.

All this resulted in a stalemate and the way out of it lived in transferring all that the draft constitutional act contained to the legislative level and having it passed by the votes of the ruling coalition, which holds a comfortable majority. The ruling coalition made such a definitive strategic decision in autumn 2017, when the proposal in the form of a constitutional amendment was in October 2017 rejected. One of the reasons why this strategic move might be plausible was that, as attested to by examples from other Member States as well as by specific statements by representatives of the Commission of the EU, the European Union does not require that the rules of predictable budgeting be enshrined at the constitutional level. The law was published as No. 23/2017 Coll.

The solution described above, when applied, ultimately led to a situation where the most specific proposal induced by the 2008 financial crisis would leave no traces at the constitutional level in the Czech Republic.

\section{CONCLUSIONS}

The 2008 financial crisis did not bring about a breaking point in the Czech Republic constitutional development. This opinion includes bills submitted, but not approved. If the individual categories of proposals defined above are considered based on whether they have any causal links to the financial crisis, the following conclusions may be reached.

40 On the selected solution see also Antoš (2015).

${ }^{41}$ Chamber of Deputies' Papers No. 412, Term VII. For the sake of completeness, it should be added that the bill amending a whole range of other acts in the context of the passage of the constitutional act and the fiscal responsibility act may be consulted in Chamber of Deputies' Papers No. 413, again for Term VII. 
On average, every election term, there are about ten to twenty draft amendments to the Constitution submitted, whose scope generally tends to be broad and diverse. There were practically no changes after 2008. A certain shift may be observed in this field, which is related, among other things, to the second category of the drafts under consideration, where a relation to the financial crisis is possible, yet apparently very weak.

In the Czech Republic, a social and political trend has been witnessed which calls for greater transparency and accountability in public life, combined with anti-corruption appeals. This is also related to a certain weakening of the political parties that established themselves on the political scene after 1990 and are referred to in the Czech discourse as 'traditional' political parties. In this sense, the first group of drafts includes, but is not limited to, such themes as, for example, direct elections of leading representatives of territorial self-governments. The requirement for financial oversight in respect of the management of political parties and regulation of election campaigns also appeared in the political discourse. These suggestions, however, did not attain constitutional relevance.

The 2008 financial crisis undoubtedly had an impact on the scope of social rights. In this case, however, the change did not bring any added quality. The admissibility of the changes had then been known for about 15 years, a fact that is clearly attested to by the text of the Charter of Fundamental Rights and Freedoms and that was confirmed by the Constitutional Court in its case law soon after it had begun to operate. What is more interesting regarding the period under consideration, compared to the preceding periods, is the quantity, or the scope of the changes that occurred. Another interesting thing about the period is the fact that it confirmed that the scope of social rights may change in either way, i.e., either be narrowed, or extended.

The principal thing, from this viewpoint, is the proposal for the constitutional foundation of the limits of public debt and the corrective action designed to reduce it. It has been shown ideologically, the draft is not an entire novelty but the financial crisis led to a relatively serious discussion on the topic. With regard to the current distribution of political forces, however, the Czech Republic is not likely to establish fiscal responsibility rules at the constitutional level. On the other hand, all major political parties stress the need for sustainability of public finances and subscribe to practical policies that will help to achieve the objective, regardless of whether it is enshrined at any legislative level.

Therefore, the 2008 financial crisis did not bring about a constitutional breaking point in the Czech Republic. In spite of that, as stated several times above, the Czech Republic and its political system is undergoing changes that are not directly linked to the financial crisis. The system of political parties is somewhat eroding, with traditional parties losing support in favour of 'non-political politics', so to speak. ${ }^{42}$ In the Czech Republic, there is a rise of new political parties and movements, usually established by 'old politicians' to serve a single purpose and hardly ever surviving a single election term, as well as increased calls for the introduction of elements of direct democracy, including the impeachability of

42 However, in a certain distorted fashion. The term 'non-political politics' has been used in the Czech lands ever since the 19th century as an equivalent to the building of a civil society and everyday public engagement, without the need for the involvement of public administration bodies. The historian František Palacký and the journalist Karel Havlíček Borovský in the 19th century and the first Czechoslovak President, Tomáš Garrigue Masaryk, in the 20th century, all operated with the concept. The last major proponent of the concept was Václav Havel, who promoted a philosophical/ political concept of politics based on civic engagement and horizontal, often ad hoc, initiatives, rather than on political parties, indeed on the very opposite of political parties. 
politicians and an increase in transparency and controllability of public actors' decisions. Many aspects of this development lead to a loss of predictability of the actions taken by the new political initiatives and a loss of responsibility given by the ephemeral nature of such entities.

Although these changes undoubtedly deserve our attention, they should be reserved for sociologists and political scientists. For now, the constitutional system of the Czech Republic is not affected by those social/political changes.

\section{SUMMARY}

The paper examines the impact of the 2008 global economic crisis on constitutional developments in the Czech Republic. When analysing the issue, the author suggests not only monitoring the temporal coincidence of the submitted draft constitutional acts with the events known as the financial crisis, but also their direct substantive links with them. In essence, a temporal link is an insufficient criterion; what should be critical is whether, or not, a causal link based upon a material aspect exists with regard to each specific example. From this viewpoint, the author suggests dividing proposals for constitutional changes in the Czech Republic into four categories: proposals where no substantive links may be demonstrated; proposals where such causal links may exist, but are not certain; proposals where the existence of a causal link is highly probable; and those where such links are apparent. The article seeks to explain the Czech constitutional context and the very proactive approach on the part of politicians to the text of the Constitution and proposals for its amendments, which are however seldom signed into law. The author meticulously justifies the assignment of the drafts into the aforementioned categories and at the same time reaches a general conclusion that the financial crisis did not lead to constitutional developments in the Czech Republic that could be regarded as qualitatively novel. On the other hand, the Czech Republic is undergoing a process (independent of the financial crisis) of the erosion of the political system and the system of political parties associated with a certain amount of public distrust in the traditional system of constitutional and political representations, with the emergence of requirements calling for the strengthening of elements of direct democracy and with the rise of new entities, often self-proclaiming their being non-political and gaining more support.

\section{LITERATURE}

Antoš, Marek, 'Finanční ústava: raději maják nežli stěžeň' (Financial constitution: rather a lighthouse than a mast) (2015) Právník 26-48.

Contiades, Xenophon (ed), Constitutions in the Global Financial Crisis: A Comparative Analysis (Ashgate 2013).

Kudrna, Jan, 'Cancellation of early elections by the Constitutional Court of the Czech Republic: Beginning of a New Concept of "Protection of Constitutionality"' (2010) 4 Jurisprudence 43-70.

Kudrna, Jan, 'The Question of Conducting Direct Elections of the President in the Czech Republic (A Live Issue for 20 Years Already)' (2011) 4 Jurisprudence 1295-321.

Kudrna, Jan, 'Patching as an inevitable underlying method of approaching the Constitution of the CR.' in Gerloch, Aleš, Kysela, Jan et al., 20 let Ústavy České republiky. Ohlédnuti zpět a pohled vpred. (20 Years of the Constitution of the Czech Republic. Looking Back and Forwards) (Aleš Čeněk 2013) 84-101.

Molek, Pavel, 'Czech Presidential Elections 2013 (Feast of Democracy or a Czech Farce in Four Acts?)' (2015) 1 ICL Journal (Vienna Journal on International Constitutional Law) 90-108. 
Preuss, Ondřej, 'The eternity clause as a smart instrument - lessons from the Czech case law.' (2016) 3 Acta Juridica Hungarica 289-304.

Roznai, Yaniv, Unconstitutional Constitutional Amendments (The Limits of Amendment Powers) (OUP 2017).

'Rudé právo, Komunističtí poslanci: Volba prezidenta lidovým hlasováním.' (Communist deputies: Elections of president by popular vote) (1989) 70 Rudé právo.

Suk, Jiří, Labyrintem revoluce. (Through the Maze of the Revolution) (Prostor 2003).

Vnenk, Vladislav, 'Ústavněprávní odpovědnos prezidenta republiky ve světle připravované novely Ústavy.' (Constitutional responsibility of the President of republic in the proposed amendment of the Constitution) (2015) Právní rozhledy 744-46.

Wintr, Jan, Antoš, Marek and Kysela, Jan, Direct Election of the President and its Constitutional and Political Consequences. (2016) 2 Acta Politologica 145-63. 